\title{
Marketing of Cities as Centres of Socio-Economic Development in the Process of Globalisation
}

\author{
Sergeys Ignatyevs ${ }^{1}$, Sergey A. Makushkin ${ }^{2} \&$ Sergiy Spivakovskyy ${ }^{3}$ \\ ${ }^{1}$ Faculty of Economics and Management, Baltic International Academy, Latvia \\ ${ }^{2}$ Faculty of Management, Russian State Social University, Russian Federation \\ ${ }^{3}$ Department of Business, Higher Colleges of Technology, United Arab Emirates \\ Correspondence: Sergeys Ignatyevs, Faculty of Economics and Management, Baltic International Academy, LV-1003, \\ 4 Lomonosov Str., Riga, Latvia.
}

Received: February 16, 2021

Accepted: March 17, 2021

Online Published: April 9, 2021

doi:10.5430/ijfr.v12n4p146

URL: https://doi.org/10.5430/ijfr.v12n4p146

\begin{abstract}
Modern trends in the formation of urban development are based primarily on the extent to which the territory of a city can be attractive for investors, interested people in general and public administration systems. When regarding programs for the development of urban areas in the structure of sustainable development, it is necessary to highlight the methods of forming an attractive image of a city, which is considered a marketing tool. Understanding the possibilities for the development of an urban area requires the formation of tools for spatial marketing and opportunities for the establishment of measures for the development of individual tools of communication between city authorities and the external environment. The novelty of the research is determined by the structural feature of the formation of an integrated method of using marketing tools to promote the image of a city in the informational, social, and cultural aspects. The authors show the tools for implementing the marketing strategy of the urban area as elements of sustainable development. Stakeholders of sustainable development are shown not only local management structures but also global investment funds and transnational corporations. The practical significance of the study is determined by the possibility of forming based on an urban area, which is marked by the presence of sustainable development markers, innovative and science-intensive centres, and analytical corporations. The formation of development centres is also possible through the creation of smart cities.
\end{abstract}

Keywords: social and communication technologies, sustainable development, media environment, media, communication contacts

\section{Introduction}

The main essence of the promotion and advancement of the territory is the dissemination of information about its advantages and uniqueness in the information space. Information is called the driving force of modern high-tech marketing, recognising the direct dependence of its success on the effectiveness of the information system, on a well-structured information environment that is constantly updated. A successful identity, a well-articulated brand mission and vision, a city and its drivers "main messages" will not work if the constant presence of the territory brand in the information space is not ensured (Merrilees et al., 2013; Topchiy \& Shatrova, 2018). Accordingly, the main task of initiators and marketing coordinators is to ensure the circulation of marketing information, to establish information flows at regular intervals, targeted at various audiences of the city's brand (Gómez et al., 2018). In communication marketing activities, two successive stages can be distinguished: the wording of "messages" about the advantages of a certain territory (city); delivering "messages" to the target group in the most effective way.

Therefore, an important prerequisite for system branding is the existence of a competitive interactive media environment, for which it is necessary to closely cooperate with advertising and design agencies, with the media. They associate with close cooperation with the media the promotion of their unique brand in the information space within the captious marketing of the territory of large and small cities, expecting that this will increase their competitiveness.

The marketing communications system should provide for several streams of information messages (Herstein et al., 2012): 
- Full information about the essence, goals and opportunities, results for the region of certain projects in various fields (economy, education, culture, sports, ecology, tourism, etc.);

- Promoting a positive image of a territory;

- Underlining and broadcasting the identity of a region;

- The formation of a system of values as a centre around which residents should unite, ensuring tolerance towards representatives of various national, religious and similar groups.

It is thanks to communications that the interests of all subjects of the territory are coordinated and balanced as a prerequisite for the implementation of a marketing strategy. In the branding process, active players (actors) who lead the process plan communications at several levels: selection and ranking by the importance of events, intentions of participants in branding processes; the dissemination of information about them based on the determination of the target orientation, the temporal and spatial organisation of communications, the choice of the form of brand messages in the operational context with the participants in the strategic context. Communication in the context of branding is understood very broadly, recognising that territories "communicate" about themselves using various systems of signs - visual, verbal, sound, and the like. Some communication systems are poorly managed, while others, provided they work systematically, can form or adjust the image of a particular brand (Ma et al., 2020; Topchiy \& Bolotova, 2020). Now the need for a multifaceted influence on the public environment using innovative technologies is recognised. The evolution and integration of social and communication technologies, communication tools, which is fully manifested in the marketing process, can be stated.

The totality of information carriers about the brand's historical and cultural characteristics of a city is almost limitless. They include: signs for delimiting territories, marking their boundaries and outlines (boundary signs), other road or field natural or man-made landmarks (in particular, ordinary road signs); official and unofficial symbols (emblems and coats of arms of cities, territories, characters related to them); geographical maps and diagrams (the authors emphasise the importance of even showing geographical maps in television weather broadcasts as brand identifiers, a reminder of its integrity and unity); local natural environment, landscape features; books, albums, reference books, brochures, calendars, postcards, envelopes, school notebooks, notebooks, diaries, etc. with logos and other visual means of reminding about the brand; local museums (however, it is important that they are not an accumulation of dust and debris, but are organised using modern technologies, interactive); mass media; badges and souvenirs; city and regional codes (automobile and telephone); artistic and other artistic works. Songs (first of all the so-called "geographical" ones, containing toponyms, ethnonyms, anthroponyms, assessment of specific places), folk art are another emotional carrier of information about the brand. The authors, thus, recognise the new role and function of history and culture in modern public life, speak of the innovative use of the historical and cultural characteristics of a region. It is important for the subjects of each brand, first of all, the authorities of each locality, to audit their assets, their economy and find out whether they are being used effectively. Pointers with the names of settlements, car navigators (entrance steles and road signs), diagrams, etc. can be turned into cosy corners and a place for photographing, carriers of important information.

\section{Literature Review}

Information about the region to each potentially interested person can be provided purposefully or accidentally, incidentally, in two ways - thanks to his communication experience and the data that the person receives from different sources (Lapidus \& Makarov, 2016). According to G. Muratovski (2012), the communication activity of a city, of any other settlement, is realised in all actions that create its image. There are no trifles in marketing processes; any detail, as a carrier of information about a location, can become a key element of the city's message to the outside world, which affects its image and attitude towards it (Björner, 2013; Jurgaitis et al., 2019). It is often said about a generalised understanding of the perception of the territory through certain types of texts, such as a set of symbols, images, stereotyped statements, communication signs and reputation characteristics (Fernando Rey, 2016). E.V. Harapko (2019) believes that the image of the nation-state and its territories is formed by its various types and many discourses. Q. Yang et al. (2018) divided the texts in the context of branding territories into:

- Authentic (by which they mean historical facts, political events, decisions and defining persons, mentality, cultural heritage as close to reality as possible);

- Official (self-presentation of territory, which is officially adopted and broadcast by marketing subjects, other interested parties);

- Private (spontaneously constructed assessments, attitudes and ideas about the territory of ordinary citizens - its inhabitants and external observers). 
C.-S. Chan \& L.M. Marafa (2014) consider that these types of texts coexist and circulate simultaneously, having their authors, communicators and recipients, differing in purpose and broadcasting channels, as well as openness to correction, intervention and direction in the plane necessary for marketing subjects. The least controlled, but quite influential and more acceptable in a wide audience, is a private text as the quintessence of spontaneous opinions and assessments of territory in the mass consciousness (Joo \& Seo, 2018; Lapidus \& Yves, 2018). The basis for the formation of such messages can be not only real impressions based on their experience of "communication" with territory but also rumours, gossip, replicated patterns and clichés of perception of certain territorial objects (Braun, 2012).

According to M. Kavaratzis (2009), a large array of marketing information is disseminated spontaneously through social networks, as multidimensional and parallel network content on urban life, which is produced by co-authors of an urban brand, territorial identity. Such a source of information about the location as representatives of professions with a significant volume of daily informal communication cannot be excluded (Kavaratzis \& Ashworth, 2005; Soltani et al., 2018). These can include taxi drivers, hairdressers, service station workers - with regular communication contacts, whose interests can also be realised in the marketing process (dos Santos, 2020). Each region transmits information about itself in different ways: in the form of official texts and through the practice of life (Oguztimur \& Akturan, 2016; Rudenko, 2019a). C.E. Henninger et al. (2016) proposed to define the branding of a territory as a system of communicative-sign interactions that are carried out within a certain communicative channel and are manifested in the aggregate of their verbal and non-verbal components. There is a direct definiteness of the success of the communication campaign through thoughtful planning: the focus of the message on real and relevant goals for the audience; maintaining interpersonal communication in the conditions of mass dissemination of information.

With the recognition of the transactional nature of public communication, its dialogic nature, the necessity of coordinated actions and meanings in interpersonal communication is proved. T. Moilanen (2015) think that the marketing project (as a kind of communication) must be long-term, and its implementation must be continuous. All this determines the need for marketing initiators to develop a program to influence all types of texts, to ensure their positive focus on brand promotion (Hospers, 2020; Katranov \& Lapidus, 2018). In creating the desired image of any marketing object, the activity of architects is important first of all (although the results of their creativity, as well as in more ancient times, before the spread of verbal texts, were the translators of messages about the territory to stakeholders), specialists who organise communications and life processes within the territory and represent its interests in external communication processes (Jokela, 2020; Rudenko, 2019b). However, all previous research has focused on the studied reduction of uncertainty and effective decision-making in marketing problems. This work is an attempt to fill the gap, namely to explore the development of marketing activities in the context of economic globalization.

\section{Materials and Methods}

Since territories are primarily people, both as brand carriers and as its consumers, it is important for the effectiveness of marketing communication to take into account the characteristics of the modern audience, its approaches to receiving information and making decisions. In modern society, the parameters and characteristics of consumers of marketing information are changing: lack of illusion, scepticism and caution dominate; the desire to receive information for making decisions on the purchase of goods and services not from advertising messages, but from other independent, authoritative informal sources for them: from friends, relatives, neighbours and the media. Now it is worth recognising a significant change in the characteristics of the media audience, to which marketing information is also directed.

The modern media audience is characterised by a different perception of information in conditions of oversaturation with visual images. It has certain difficulties in maintaining attention within a homogeneous information series, the ease of its switching; it has an inherent ability to work in a multitasking environment; dynamism, mobility, technological equipment with information retrieval tools; in the conditions of the openness of the information environment, independence from specific media was formed in meeting their information needs (news, analytical, literary and artistic); lack of information hunger, on the contrary, there is information redundancy.

\section{Results and Discussion}

\subsection{Features of Cities Development in the Process of Globalization}

The world of the modern human is changing rapidly, which can be traced in all social spheres. To nominate new concepts and processes that shape the face of a new reality, terms inevitably arise or are borrowed, which are rapidly 
spreading. In the list of neologisms that are significant for present (mondialism, glocalisation, stereotyping, ethnic management, ethno-globalistics, regional studies), researchers also name branding. It is branding that can now be recognised as a global social trend. After all, globalisation, development and improvement of information and communication technologies, further capitalisation of all spheres of public activity are not only the driving forces of civilisational progress, they also form new challenges and tasks.

In the context of the mediatisation of the world, there are grounds to talk about the formation of a symbolic market for local images, which can be considered as a special type of product. Cities and the whole territory become participants in such a market. To characterise the modern economy and economic processes, a number of definitions are used, with the help of which the authors seek to "capture" and designate the nature of these transformations. Economists call the modern format of the world economy, extrapolating social patterns to it, due to the dominance of certain trends and tool the information economy, or the knowledge economy, emphasising, in particular, such a feature as the development of the phenomenon of brands and branding. The shift of the main emphasis of geopolitical rivalry to the economic sphere contributed to the emergence of such definitions of the economy as "network", "innovative", "symbolic", "Internet economy", "the economy of impressions", as well as the formation of an economy of values based on the unique value propositions of manufacturers and the ability of business entities to choose a strategic role in the social, economic, cultural processes of society.

Now researchers state a convincing change in the perception of the essence of economic processes, decision-making mechanisms in the economy, their "humanisation": the advantage of the "experience economy" is achieved due to the focus on "mass personalisation", on consumer feelings. The psychological factors that determine even economic realities are becoming more and more noticeable. If branding of a product or service is aimed at creating an attractive media image of a commercial proposal in order to enhance sales and successful competition, then the purpose of branding a territory is not selling in the literal sense, but attracting "development resources" (attention of authorities, investors, customers, population) in exchange for benefit, which is determined by the use of natural and human potential, location, cultural and educational traditions, the historical heritage of the region (Goncharenko et al., 2018).

Scientific interest in territorial branding as a technology for promoting and increasing the popularity, competitiveness and innovative ability of settlements, cities, the country as a whole, improving the attractiveness of the region for various groups of stakeholders, which can be capitalised, appeared at the beginning of the 21 st century. Although the pragmatic task of including territories and products (in the broadest sense of the word) in competitive relations, the task of their image and reputation self-identification, informing about themselves in the new economic and political conditions had been actualised much earlier (Borges et al., 2020; Trusova et al., 2018). The modern consumer of public goods and services is already guided by another system of values: having more free time, he is ready to spend it on self-development, spiritual practices, free employment (freelance); he critically analyses the information received, which predetermines his great pickiness, refined tastes and needs. Such a consumer is less vulnerable to the influence of manipulative technologies due to the skills of critical thinking and media literacy; he is interested in obtaining information from various sources, establishing its reliability; he knows how to receive information instantly, adjust his attitude to something, the impression of something depending on the new data (Arenkov et al., 2019; Sidorova, 2015).

As a result, he receives not a static image of the object of interest, but a dynamic, flexible, plastic one. In addition, a citizen of a modern society has a different set of objective characteristics: the authors point to an increase in the age and educational qualifications in European countries - for travel, participation in public projects and movements; increased activity of women, expansion of their spheres of activity; an increase in the number of single-parent families; education of families in non-traditional forms. Needs for a healthy lifestyle, environmentally friendly products, expanding horizons and raising the cultural level, extreme entertainment is formed. With this in mind, a person approaches the choice and assessment of a city brand. Therefore, the latter's important key and systemic messages about himself should be clear, convincing, modern, taking into account the named characteristics and expectations. Positioning should use a wide range of forms of presenting the brand to a wide range - complex self-identification, which includes: communication (name, logo, slogan, texts, direct speech of authority figures about a territory); visual (identity); sonar (sound).

Many attempts are now being made to systematise the many and very diverse communication tools that are used in marketing. The classification is usually based on the distinction between traditional and electronic methods of transferring information, highlighting online and offline tools. The first group includes sites of a territory; official accounts in social networks: Facebook, Twitter, Instagram and the like; development of computer games related to 
the territory; system of QR codes; online guides; mobile versions of media sites. Offline tools, in turn, are divided into event tools; cooperation with the media; editions. The most effective event channels for participation in the location competition are considered to be holding various events to attract target audiences (festivals, quests, marathons, concerts, light shows, sports days, competitions, biennials); development of tourist routes that broadcast certain features of a territory; participation of territories in competitions/ratings; own competitions of a territory; day of a certain territory. Cooperation with the media is planned in such proven formats as press tours, press lunches, press conferences; organisation of press offices. Editorial and publishing activities use a wide range of opportunities that, in conditions of a high level of printing, contribute to the achievement of the desired result (guidebooks; territorial media).

Leaving the distinction between online and offline channels as the basis for the classification, the authors consider it possible to expand the list of offline varieties, starting from a broad understanding of marketing communications, with such blocks as: architectural and spatial communication tools and product-based communication tools. Architectural and spatial include the saturation of public space with creative elements (street art, interactive sculptural compositions, creative solutions in the field of landscaping, the creation of urban "furniture", small architectural forms, etc.). Modern cities are quite creative and unconventional in their approach to the formation of a network of attractive places, taking into account the historical potential and the use of new technologies of the experience industry, as evidenced by the strategic plans for the development of regional centres. Subject-commodity communication can be represented by clothing, stationery, gastronomy with a brand logo, and other symbols. The authors also propose to add a third group - the so-called syncretic marketing tools (which can have both online and offline formats), which include various advertising texts, identity, and the like (Akhmetshin et al., 2018).

They often talk about the development and implementation of a communication PR program as an effort aimed at rethinking and popularising urban symbols (the official symbols of a city are the coat of arms, flag, anthem; architectural and memorial symbols; verbal symbols, etc.). This also includes the successful use of external communications, indicating that such work should be carried out constantly. F. Kotler identifies three components of public relations: working with the media, organising events and lobbying. Scientists, considering advertising and public relations as different types of pragmatic communications, call such a common characteristic of them as focus on results. Other authors have recognised the usefulness of using these tools at various stages of branding, considering public relations the best way to build a brand and advertising as the best way to support it.

\subsection{Advertising as a Tool for Communication and Marketing Strategies}

Nowadays advertising remains one of the key communication marketing tools (social advertising, outdoor commercial advertising), and, consequently, marketing tools. However, advertising in product branding and branding has significant differences, since in the second case it is less focused on sales, its other goals are actualised. Researchers argue that even modern commercial advertising, carried out in isolation from branding, its principles and laws, cannot fully fulfil its main role - to be a means of creating the image of a product (service) or company. Advertising, as an important component of branding in modern conditions, is changing, acquiring various forms. Advertising is a deeply thought-out and scientifically organised process with the active participation of psychologists, marketers, screenwriters, directors, designers, stylists, and sociologists. In practice, the possibilities of social advertising campaigns are widely used to ensure a permanent positive brand presence by placing marketing messages on outdoor advertising media. The new conditions require the reorientation of communications, including advertising and information, to partnerships, even friendly relations with recipients. In the context of marketing tasks, the functional accents of advertising are changing - the information function is replaced by a communication function that involves dialogue and feedback. The function of stimulating demand increasingly reveals the signs of the function of its regulator. The term "modern advertising" is spreading, in contrast to "traditional advertising," as it meets new market objectives, including marketing ones (Litvishko et al., 2020; Borodin et al., 2020).

In the context of globalisation trends, advertising texts must take into account and reflect, broadcast regional features: socio-economic characteristics of the development of a territory; regional (including intercultural) communication; national traditions and culture; religious beliefs; linguistic dominants; consumer preferences and habits. However, today there is a real threat of degradation of the traditional symbolic world of values and images under the influence of a global cultural wave in the information space. Across the world, it is considered more cost-effective to attract local buyers, but this approach has not become dominant. The main business interests are located in the metropolitan area, therefore advertising and other communications are aimed at the metropolitan audience.

The analysis of marketing practice showed interesting advertising solutions aimed at potential audiences with different locations. The role of the media in organising modern public life cannot be overestimated. It is they who 
now have the prerogative in defining trends, priorities, forming recognition or rejection of certain social ideas, realities, tendencies. Recently, this has been estimated by experts as a period of activation of the transmission of meanings through the media. Interpretation in a light favourable for the territory becomes one of the mechanisms of its branding. Given this "omnipotence" of the representatives of the "fourth estate", even in democratic European countries, the local authorities are trying to maintain business relations (including through press teams at the mayor's office, other institutions) with the system of mass communications bodies (mass media), which are effective creator's public opinion. The basis for such cooperation is the promptness of providing them with information, full informing them about decisions and initiatives that are crucial for the region, city, settlement, about which the widest audience should learn. In marketing practice, the media are qualified even as elements of the brand, as agents of the city's brand, which will contribute to the conduct of events to popularise it. Activities aimed at widespread involvement of media professionals in branding activities are typical for many regions (Trusova et al., 2019).

The regional media are assigned the function of organisers of social communication in an "imaginary community" by creating a common semantic space, influencing the quality of social ties, and forming an integrated local community, local symbols and attributes. All of the above ultimately determines the level of regional patriotism and forms the image of a territory. It is the regional media that form a sense of community with the inhabitants of their region, the presence of a single communication field; the opportunity to feel included in the life of society, in the life of one's own city, which gives a sense of competence and confidence in life, and sometimes a sense of involvement in events. The main functions of local media, as in previous years, are considered to be timely, full disclosure of local events, coverage of important local problems, presentation of the views of key persons in the region, practical assistance in social and domestic needs, orientation in cultural events. In addition, experts formulate positions that require special attention, revision and improvement by regional media (Dotsenko, 2017; Hobrei, 2020).

- Relevance and efficiency (local media are accused of focusing attention on minor issues, in providing information with a significant delay).

- Introduction to the local cultural space. The submission of an overview of local cultural events to the local mass media is still unsatisfactory. Television lacks programs with interesting local personalities, artists, scientists (although it is the local theme that ensures the revival and popularity of the media in the world, forming the uniqueness of their content in comparison with national media, which they cannot compete with in terms of efficiency of coverage of other topics).

- Interactivity of the media as a function of a mediator in the dialogue between citizens and the authorities and an initiator of discussion of topical local problems, action plans of local authorities. TV channels are often not ready to organise such a dialogue on a professional level.

- The low professional level of journalists remains a serious disadvantage of many local media outlets. Most of all comments are about the announcers, the quality of the equipment, filming, the outdated design of the studios, the ugly "picture" that lacks the dynamism that pleasant, active, resourceful presenters could provide.

- Lack of own style of presenting information, work on the formation of the "face" of a particular mass media.

The authors have identified the media as a special segment of marketing stakeholders, as the most active, professional and influential audience in terms of disseminating information about the territory. Therefore, it seems expedient to encourage media professionals to participate in local history, historical, sports media projects, to participate in professional competitions, to stimulate activity. Thus, in the branding strategy of each region, each locus, the levels, formats and forms of cooperation with the media should be clearly delineated. It seems appropriate to develop certain brand drivers (they can be called messages or narratives), the disclosure and interpretation of which by local and national media would have a good effect in the process of brand promotion. Analysis of strategies for the development of regional centres, confirming an understanding of the potential of such a tool as hosting local events that have an international scale and level, or the format of marketing events.

\subsection{Analysis of Strategies for the Socio-Economic Development of Cities}

Development strategies of regional centres also plan to expand the list of events of an entertainment, tourist, cultural and artistic nature, which will yield marketing results. In modern conditions, it is important to constantly update the format of the mentioned marketing tools, which will confirm targeting the audience and will reflect current trends in the development of public communications. Both genre-conceptual characteristics and content principle of information concentration can be original. For example, in the city of Zoetermeer, where a youth audience was chosen as the key for marketing influence, new directories and comic books were published to highlight the main attractions of the city precisely for this category of consumers, with the desired result. That is, the marketing 
communication toolkit must match the characteristics of the audience (Shavina \& Prokofev, 2020).

Calendars - festivals, scientific conferences, "city events", etc., are becoming a widespread format for replicating information, which are not only a convenient format for presenting information of a certain type, but also indicate the systematic nature of work in a certain direction, being also a means of self-control. The positioning of the regions requires new active and bright projects. Their task is to focus on the quality of cultural projects, overcoming a simplified approach to the interpretation of social and cultural events, establishing interaction and mutual understanding between different environments, seeking consensus on complex issues, overcoming the closeness and marginalisation of certain groups, intolerance.

The cultural space is being renewed in other cities - theatres, concert halls, museums. Identity (or in foreign practice "corporate ID" or "brand ID", where ID is an abbreviation of the English word "identity") is a visual reflection of the vision, values and strategic goals of territorial development. Otherwise, it is called corporate identity, a corporate identity system. In commercial branding, corporate identity is defined as a series of techniques (graphic, colour, language) that ensure a certain unity of all products of an enterprise (firm, company) and distinguish them from competitors' products. The same understanding is relevant for marketing. The elements of corporate identity are: $\operatorname{logo}$ (specially designed original outline of the full or abbreviated name of a company or its product, city), corporate block (compositional unity "sign and logo" with explanatory inscriptions (country, address, phone numbers, corporate slogan, musical accompaniment, etc. like)); corporate colour; typographic element - corporate set of typefaces; corporate constants (style, page making and illustration).

After the formation of all the named components based on taking into account the historical past of a location, trends of modern development and aspirations, after a broad public discussion of projects developed by professionals, they should be documented, fixing the main positions: brand-book, which, by definition, is a book with simple pictures in artistic style for widespread use; in Brand marketing guidelines - a marketer's book for a narrow circle of specialists who will directly bring to the market and adjust a brand; Brand design guidelines - a guide for designers who will prepare presentations and design brand products. The most widespread was the first brand book format. Typically, the corporate identity (colour and font solution, logo, slogan, etc.) is used in all possible communications of a city: in a city navigation system, in road signs, in outdoor advertising (billboards), in public transport. The carriers of corporate identity elements are printed advertising, souvenir advertising, means of decorating halls for press conferences, corporate publications, office work elements, elements of office interiors.

Development strategies of almost all regional centres provide for the creation of high-quality information and presentation products, which, together with souvenirs, can be considered as a means of prolonged marketing communication. Editorial and publishing marketing materials for information and presentation purposes (booklets, flyers, guides, maps, diagrams, etc.) are traditionally effective translators of marketing information. Now they provide, in addition to important information, also aesthetic pleasure: printed on quality paper, well-illustrated, are the result of professional design decisions. Practitioners recognise the advisability of preparing separate materials for different segments of the audience - for tourists, city guests and investors (Buy, 2020).

The availability of information changes the norms of human behaviour. Most modern people have certain preferences regarding the choice of certain news resources. Most people prefer the Internet over others, in particular television. According to the results of a representative online survey, official information printed on the Internet ranks second (65\%) after the opinions and advice of friends and relatives (77\%). The information that is published on forums and blogs is fully or predominantly trusted by $52 \% .38 \%$ tend to trust print media as a source of information, and 32\% - television. In planning and implementing marketing projects and campaigns, it is now necessary to focus on another generation of information consumers - who "live" in the Internet: they work, look for clients, build their careers, do business. They have a different approach to obtaining information, a different approach to consumption, and now the exchange of information "from person to person" dominates.

The experience of large and small European cities testifies to the attention to such a widely available and used tool as a city website. For example, in Poland, almost every gmina (settlement) has its own page. The main condition for the existence of the city's Internet page is that it is "alive", regularly renewed and contains up-to-date information on the activities of local authorities, announcements and conditions of tenders, implemented international projects, life and events of a city. Only such a web page can be a branding tool. Information about the work of the city authorities, as well as about tenders, land sales and competitions held by the city, is transparent and accessible. At the same time, Polish scientists emphasise that a web page requires careful and regular monitoring of a situation on the site, analysis of comments, and communication on forums.

Despite the availability of information about the advantages of cities and other settlements through a variety of 
unofficial - public and commercial web resources - the city government is an important and authoritative translator of the city's information policy and integrator of all information flows. Therefore, its task is to ensure openness to all significant urban public and commercial initiatives, which can be strengthened with the help of official information channels, first of all - the official website of a city. However, as shown by the authors' general review of the official websites of cities - regional centres for the placement of marketing and image information, the latter is served there in a sporadic, irregular update mode in the following main areas (blocks): historical information about a city (not always well structured and properly illustrated); city symbols; cartographic materials; information about honorary citizens and famous countrymen.

Among the tasks of development, first of all, the tourist direction provides for several levels of information placement:

- disseminating information and reviews on the popular travel site TripAdvisor;

- improving the tourist web-portal as an important tool for marketing communications, with information about a city and the main tourist attractions in a region;

- bringing a portal to leading positions in search engines and its promotion through the placement of banner ads on popular travel sites;

- $\quad$ work on the development and distribution of marketing messages of information and navigation content aimed at proactive tour operators and the target audience;

- creation and promotion of a modern city tourist portal with an international domain name travel or visit;

- new pages on Facebook and on city websites;

- the formation of a multilingual directory of an official tourist web portal of a city council.

However, such measures are sporadic and unsystematic, and their effect cannot be noticeable. More effective is a comprehensive brand promotion program in the domestic and international markets, proposed by strategic documents on the positioning and promotion of a city brand, which provide for such an operational goal as modelling the information space of a brand, taking into account all possible effective communication tools, using the potential and capabilities of all those interested in promoting brand, as well as organisational, control, monitoring activities. According to this, it is planned to: create targeted programs of information and marketing activities for each segment of the target audience; development of low-cost branding projects (through internet branding, using the capabilities of the brand community in social networks, using for branding purposes interesting content of users of social networks to promote the city's brand (User-generated content); it is planned to promote the sustainable presence of a brand in the information space at the local and regional levels thanks to the media; promoting the emergence of English-language publications for the international community, foreign stakeholders in foreign media, and the like; forming a database of information messages regarding the city's brand. Many interesting initiatives are planned in other formats. The importance of cards for marketing as attributes of integrity has already been noted and the unity of a territory, and not only as carriers of cartographic information.

\section{Conclusions}

Taking into account current trends in the educational and entertainment industry, it is planned to activate new types of tourism, among them those that are aimed at using the features and advantages of the territories. The understanding of the museum concept is also changing in modern conditions. If in the world these institutions have long been formed on the principles of entertainment, interactivity, scientific progress and technological effectiveness, then in many countries only the first steps are being taken. Interactivity is becoming the basis of modern cultural and artistic events - it is planned to support the development of interactive museums. As the analysis of urban development strategies has shown, active efforts to disseminate information about the possibilities of cities will be directed specifically to the Internet space.

Usually, even the most successful channel of communication does not give the desired effect. Depending on the goal, objectives, marketing stage, brand and audience characteristics, budget, their optimal complex is formed. This approach is called integrated marketing communications. Each component implements its tasks: thanks to advertising, brand awareness is achieved, its image is formed, for this, reputation and favour is formed.

\section{References}

Akhmetshin, E. M., Dzhavatov, D. K., Sverdlikova, E. A., Sokolov, M. S., Avdeeva, O. A., \& Yavkin, G. P. (2018). The influence of innovation on social and economic development of the Russian regions. European Research Studies Journal, 21(2), 767-776. 
Arenkov, I. A., Salikhova, I. Y., Ivanova, D. V., Smirnov, S. Đ., \& Rudenko, M. N. (2019). Intellectual capital factors in enhancing competitiveness of retail network. In Proceedings of the 33rd International Business Information Management Association Conference, IBIMA 2019: education excellence and innovation management through Vision 2020 (pp. 2571-2574). Granada: IBIMA.

Björner, E. (2013). International positioning through online city branding: The case of Chengdu. Journal of Place Management and Development, 6(3), 203-226. https://doi.org/10.1108/JPMD-03-2013-0006

Borges, A. M., Sakulyeva, T. N., Tulenbayev, Z. S., Kozhageldi, B. Z., \& Karabassov, R. A. (2020). Exogenous and endogenous factors of innovative development of the oil and gas corporations. Journal of Environmental Management and Tourism, 11(5), 1231-1239.

Borodin, A., Ziyadin, S., Islyam, G., \& Panaedova, G. (2020). Impact of mergers and acquisitions on companies' financial performance. Journal of International Studies, 13(2), 34-47.

Braun, E. (2012). Putting city branding into practice. Journal of Brand Management, 19(4), 257-267. https://doi.org/10.1057/bm.2011.55

Buy, J. V. (2020). Institutional provision of social innovations in the conditions of sustainable development. Scientific Bulletin of Mukachevo State University Series "Economy”, 1(13), 11-16.

Chan, C.-S., \& Marafa, L. M. (2014). Rebranding Hong Kong "Green": the potential for connecting city branding with green resources. World Leisure Journal, 56(1), 62-80. https://doi.org/10.1080/04419057.2013.876587

Dos Santos, N. A. S. F. (2020). Crossroads between city diplomacy and city branding towards the future: case study on the film cities at UNESCO Creative Cities Network. Place Branding and Public Diplomacy. https://doi.org/10.1057/s41254-020-00174-3

Dotsenko, E. (2017). NBIC-convergence as a paradigm platform of sustainable development. E3S Web of Conferences, 21, article number 04013.

Fernando Rey, C.-V. (2016). The scope and limits of city branding in the management of the image of the city. Revista Venezolana de Gerencia, 21(73), 157-171.

Gómez, M., Fernández, A. C., Molina, A., \& Aranda, E. (2018). City branding in European capitals: An analysis from the visitor perspective. Journal of Destination Marketing and Management, 7, 190-201. https://doi.org/10.1016/j.jdmm.2016.11.001

Goncharenko, L. I., Sidorova, E. Y., Artemev, A. A., \& Nazarova, N. A. (2018). Dividend-based and interest-based schemes of minimization of customs value of goods in deals between related parties: Russian practice. Espacios, 39(16), 1-11.

Harapko, E. V. (2019). Social and demographic potential of small towns of the transcarpathian region: evaluation of development trends. Scientific Bulletin of Mukachevo State University Series "Economy", 2(12), 91-98.

Henninger, C. E., Foster, C., Alevizou, P. J., \& Frohlich, C. (2016). Stakeholder engagement in the city branding process. Place Branding and Public Diplomacy, 12(4), 285-298. https://doi.org/10.1057/s41254-016-0002-1

Herstein, R. (2012). Thin line between country, city, and region branding. Journal of Vacation Marketing, 18(2), 147-155. https://doi.org/10.1177/1356766711435976

Hobrei, M. V. (2020). Attracting direct investments in the regions of Ukraine and their impact on the economic development of the transcarpathian region. Scientific Bulletin of Mukachevo State University Series "Economy", $1(13), 147-151$.

Hospers, G.-J. (2020). A short reflection on city branding and its controversies. Tijdschrift Voor Economische En Sociale Geografie, 111(1), 18-23. https://doi.org/10.1111/tesg.12386

Jokela, S. (2020). Transformative city branding and the evolution of the entrepreneurial city: The case of 'Brand New Helsinki'. Urban Studies, 57(10), 2031-2046. https://doi.org/10.1177/0042098019867073

Joo, Y.-M., \& Seo, B. (2018). Transformative city branding for policy change: The case of Seoul's participatory branding. Environment and Planning C: Politics and Space, 36(2), 239-257. https://doi.org/10.1177/2399654417707526

Jurgaitis, A., Topchiy, D., Kravchuk, A., \& Shevchuk, D. (2019). Controlling methods of buildings' energy performance characteristics. E3S Web of Conferences, 91.

Katranov, I., \& Lapidus, A. (2018). Mobile building life cycle. MATEC Web of Conferences, 193.

Kavaratzis, M. (2009). Cities and their brands: Lessons from corporate branding. Place Branding and Public Diplomacy, 5(1), 26-37. https://doi.org/10.1057/pb.2008.3 
Kavaratzis, M., \& Ashworth, G. J. (2005). City branding: An effective assertion of identity or a transitory marketing trick?. Tijdschrift Voor Economische En Sociale Geografie, 96(5), 506-514. https://doi.org/10.1111/j.1467-9663.2005.00482.x

Lapidus, A. A., \& Yves, N. (2018). Integrated quality index of organizational and technological solutions for implementation of Burundian capital master plan. Materials Science Forum, 931, 1295-1300.

Lapidus, A., \& Makarov, A. (2016). Fuzzy sets on step of planning of experiment for organization and management of construction processes. MATEC Web of Conferences, 86.

Litvishko, O., Beketova, K., Akimova, B., Azhmukhamedova, A., \& Islyam, G. (2020). Impact of the digital economy on the banking sector. E3S Web of Conferences, 159, 04033.

Ma, W., De Jong, M., De Bruijne, M., \& Schraven, D. (2020). Economic city branding and stakeholder involvement in China: Attempt of a medium-sized city to trigger industrial transformation. Cities, 105, 102754. https://doi.org/10.1016/j.cities.2020.102754

Merrilees, B., Miller, D., \& Herington, C. (2013). City branding: A facilitating framework for stressed satellite cities. Journal of Business Research, 66(1), 37-44. https://doi.org/10.1016/j.jbusres.2011.07.021

Moilanen, T. (2015). Challenges of city branding: A comparative study of 10 European cities. Place Branding and Public Diplomacy, 11(3), 216-225. https://doi.org/10.1057/pb.2015.6

Muratovski, G. (2012). The role of architecture and integrated design in city branding. Place Branding and Public Diplomacy, 8(3), 195-207. https://doi.org/10.1057/pb.2012.12

Oguztimur, S., \& Akturan, U. (2016). Synthesis of city branding literature (1988-2014) as a research domain. International Journal of Tourism Research, 18(4), 357-372. https://doi.org/10.1002/jtr.2054

Rudenko, M. N. (2019a). Economic security of the region (Perm krai). Astra Salvensis, 7, 385-410.

Rudenko, M. N. (2019b). Institutional arrangements for the realization of regional entrepreneurial potential. Public Policy and Administration, 18(2), 209-224.

Shavina, E., \& Prokofev, V. (2020). The cluster approach in the economic and innovative development of mining region (on the example of the Kemerovo region). E3S Web of Conferences, 174.

Sidorova, E. (2015). Improvement the methods of tax regulation mechanism effectiveness assessment in the Russian Federation. Economic Annals-XXI, 155(11-12), 47-50.

Soltani, A., Pieters, J., Young, J., \& Sun, Z. (2018). Exploring city branding strategies and their impacts on local tourism success, the case study of Kumamoto Prefecture, Japan. Asia Pacific Journal of Tourism Research, 23(2), 158-169. https://doi.org/10.1080/10941665.2017.1410195

Topchiy, D. V., \& Shatrova, A. I. (2018). Formation of a basic management strategy for a construction organization in the implementation of projects of redevelopment of major urban areas. International Journal of Mechanical Engineering and Technology, 9(4), 539-547.

Topchiy, D., \& Bolotova, A. (2020). Risk management in monolithic construction. IOP Conference Series: Materials Science and Engineering, 962(2).

Trusova, N. V., Karman, S. V., Tereshchenko, M. A., \& Prus, Y. O. (2018). Debt burden of the financial system of Ukraine and countries of the Eurozone: Policy of regulating of the risks. Espacios, 39(39), 1-10.

Trusova, N. V., Kohut, I. A., Osypenko, S. A., Radchenko, N. G., \& Rubtsova, N. N. (2019). Implementation of the results of fiscal decentralization of Ukraine and the countries of the European Union. Journal of Advanced Research in Law and Economics, 10(6), 1649-1663.

Yang, Q., Lu, H., Scoglio, C., De Jong, M., \& Gruenbacher, D. (2018). A network-based approach to model the development of city branding in China. Computers, Environment and Urban Systems, 72, 161-176. https://doi.org/10.1016/j.compenvurbsys.2018.06.007

\section{Copyrights}

Copyright for this article is retained by the author(s), with first publication rights granted to the journal.

This is an open-access article distributed under the terms and conditions of the Creative Commons Attribution license (http://creativecommons.org/licenses/by/4.0/). 